УДК: $7.036+730$

ББК: $85.133(3)$

A43

DOI: $10.18688 / \mathrm{aa} 200-3-51$

E. S. Kochetkova

\title{
Horizon as a Symbolic Category in Contemporary Site-Specific Art
}

The horizon line is something visible yet illusory, quite real yet nonexistent, a coordinate in space and a mental construct. In traditional art history, this notion serves as a starting point in formal analysis, a subject of discussion about systems of perspective and peculiarities of human vision, especially concerning the landscape genre. This paper intends to investigate various strategies in contemporary art that intervene in landscape surroundings. These forms of art have a privilege of not just depicting or imagining natural phenomena but using them directly as essential components of the work. Thus, in this essay the concept of a horizon will be treated in a very "palpable" way, though metaphorical and poetical at the same time. The physical and symbolic presence and interpretation of the horizon in the art of the last five decades will be the subject of this survey.

The genesis of such practices as Land Art and outdoor site-specific sculpture is rooted in the artistic theory and public debate of the late 1960s and 1970s. The very notion of sculpture, its essence and its role in the public space were subjects of mixed opinions. Some perceived sculpture as a self-sufficient object independent from its surroundings, which can add nothing to the meaning of the piece. Others maintained that space, context, and spectator's presence were inseparable from the sculptural object and could even convey its message better than the artwork itself $[18 ; 22 ; 33]$. To appreciate the complexity and importance of questions raised at the time, it suffices to compare two views expressed by authoritative scholars of modern and contemporary art - Lucy Lippard and Rosalind Krauss. In 1977, Lucy Lippard spent a few months at an isolated farm in England, thinking that she "was escaping from art" yet unexpectedly returning "straight back to art" [24, p. 1]. This sojourn resulted in her book Overlay [24] where contemporary art practices are semantically linked with prehistoric artifacts and rituals. In her turn, Rosalind Krauss opposed such "historization" of modern and contemporary art: having rejected the accepted terminology, she suggested a new definition for sculpture as "the addition of the not-landscape to the not-architecture" [23, p. 36]. Thus, the traditional binary opposition of "nature" and "culture" was softened, as new art forms and new ways of displaying them (notably, in open-air locations) addressed their natural surroundings directly.

However, as early as in 1968, Robert Smithson, the pioneer of Land Art, called sculpture parks "limbo[s] of modernisms" [34, p. 50], implying that artworks left outside, unprotected from the elements, gradually rot, rust and end up in a sort of intermediary space "between heaven and hell," between museum and garbage heap. Instead, Smithson proposed the concept of a "site" - a work situated in a landscape, inspired by it, inseparably linked to it, and 
created from natural materials available on the spot. Smithson believed that "site" works were able to accentuate ecological, social or economic issues that influenced the landscape, which is why he preferred "sites that have been disrupted by industry, reckless urbanization, or nature's own devastation" [13, p. 165]. Such places were best suited for the newborn artistic practice of Earthworks, where physical changes were applied to the surface of the Earth and affected its aesthetic qualities - however, this was done without any foreign material ${ }^{1}$. This method may seem quite plain from a purely aesthetic viewpoint, and yet it is at once labor-intensive and highly expressive as the Earth can take on some uncharacteristic properties. For example, in Maya Lin's Wave Field, (2007-2008, Storm King Art Center, New York State, USA), where an area of over $20000 \mathrm{~m}^{2}$ is modeled as a sequence of grass-covered earth "waves," about $120 \mathrm{~m}$ long and 3 to $4,5 \mathrm{~m}$ high, land looks similar to water, to something fluid and movable rather than heavy and static.

Sometimes such projects can reach colossal, almost superhuman scale. For instance, in Michael Heizer's City (since 1972, Nevada Desert, USA), one cannot see the real horizon line anymore, the spectator is fully immersed in the space constructed by the artist. For Heizer, size is an important part of the sculptor's repertoire: "With size you get space and atmosphere: atmosphere becomes volume. You stand in the shape, in the zone" [21]. Size allows "to build a sculpture that attempts to create an atmosphere of awe... Immense, architecturally sized sculpture creates both the object and the atmosphere. Awe is a state of mind equivalent to religious experience" [16, p. 33].

Such large-scale interventions into landscape can sometimes change its natural configuration completely. Thus, in Christo and Jeanne-Claude's Valley Curtain (1970-1972, Colorado, USA), the horizon line is masked, concealed, hidden from the eye, and yet accentuated with some dramatic quality.

An object put into a landscape can also "complete" this landscape in the viewer's imagination. A brilliant example is Richard Serra's Sea Level (1996, Flevoland, Netherlands), composed of two concrete walls $200 \mathrm{~m}$ long, which literally cut into the slightly sloping hillside, their strictly horizontal upper edge marking the actual sea level well above the ground. The work draws attention to the incline of the land that seems natural but is in fact the result of human intervention, as these territories were reclaimed from the sea. The new object "puts the historical record straight" and visually reinstalls the perfect horizontality of the sea level [9, p. 117].

The choice of place for the work is of crucial importance: as Ian Hamilton Finlay sharply put it in his Unconnected Sentences on Gardening, "installing is the hard toil of garden-making, placing is its pleasure" $[1, \mathrm{p}$. 40]. This practice of meticulously choosing the place for the artwork is based on the Minimalist concept of site-specificity: works may be abstract and convey no meanings as they are, but they receive certain interpretations in the process of interaction with the spectator and the place for which they were intended. An exemplary case of this site-specific approach is the notorious Tilted Arc by Richard Serra: in 1981, this massive steel

Smithson chose such kinds of sites for his own Land Art pieces, including the famous Spiral Jetty, to be discussed further in this essay.

$2 \quad$ Finlay followed the tradition of $18^{\text {th }}$-century garden theorists (notably William Shenstone and his Unconnected Thoughts on Gardening, 1764) and expressed his views in the aphoristic Unconnected Sentences on Gardening (in some sources also referred to as Detached Sentences on Gardening) [1, p. 40]. 
construction was installed in New York's Federal Plaza; however, the public and authorities were less than happy about it, as it was a vivid reminder of the Iron Curtain. The official reason for complaints was that pedestrians could not cross the square anymore and had to bypass the construction. In 1989, after a legal process, Tilted Arc was dismantled; the artist was offered to find a new place for it, but Serra declined, convinced that relocation would mean destruction of the work [2, p. 607]. In accordance with these principles, Alfio Bonanno, the creator of TICKON and Himmelhøj sculpture parks in Denmark, believes it necessary "to accentuate the feeling of a place," for "the work needs the site to breathe and function" [9, p. 236].

In Antony Gormley's Firmament (2008-2010, Jupiter Artland Sculpture Park, West Lothian, Scotland), the artist needed a minimalist background and specifically searched for a place with an open, unblocked horizon, so that the metaphorical figure of an "atlas" supporting the roof of heaven, as if drawn "in the round" with metallic "lines," could be perceived in its integrity. To achieve this, the artist's contractors had to displace almost 100000 tons of soil - such heroic efforts are more and more common in site-specific projects [9, p. 263]. In contrast, Neil Dawson in his Horizons (1994, Gibbs Farm Sculpture Park, Kaipara Harbour, New Zealand) took the natural terrain undulations into account, and made the horizon line "refract" as through a prism, between the lines of his giant semi-transparent "handkerchief" constructed of metal rods and mesh.

Inoue Bukichi's My Sky Hole (1985-1989, Fattoria di Celle Sculpture Park, Pistoia, Italy) offers a different option of "refraction" - this work is a glass cube accessed via underground passage. Once inside, the viewer sees the surrounding Tuscan hills and groves differently, they are literally deflected through the prism of the object's transparent walls. This work is a witty inversion of the Modernist "white cube," in which nature becomes the exhibit that is, however, located not inside the "exhibition space" but outside of it. Moreover, this work ponders on the idea of an impenetrable glass wall between the viewer and the artwork, and thus, on the limitations in the viewer's perception [11, pp. 203-204].

It is not always necessary to change and transform things on purpose; sometimes it is enough to concentrate the viewer's attention on the real horizon line, turning it from a nonexistent, constantly withdrawing place into almost a tangible object fixed in space. Some artists opt for delicate interventions, adding small details to the landscape that can be easily removed and often disappear after the photo-shoot. This is the method used by Francisco Infante (Near in the Far, 1997, various locations in Russia and Europe), Zander Olsen (Tree Line, since 2004, various locations in the UK) or Nicolas K. Feldmeyer (Towards the Horizon, 2016, Fanø Island, Denmark). These interventions reveal the inner structure and geometry of nature - in a sense, they are modern takes on Cézanne's famous quote about dealing "with nature by means of the cylinder, the sphere, and the cone" [5, p. 180].

A similar approach can be found in the work by Richard Long who chose walking as his predominant method and medium (see, for example, his Walking a Line in Peru, 1972). His walks leave delicate traces in the landscape, whether they are trodden paths or stones arranged in certain patterns. The artist believes that his work reaches "a balance between the patterns of nature and the formalism of human abstract ideas like lines and circles. It is where my human characteristics meet the natural forces and patterns of the world, and that is really the kind of subject of my work" [25, p. 250]. 
It is important that the geometry and patterns of nature can not only be observed visually but also perceived with all senses, as bodily experiences. In 1968, Walter de Maria created his Mile Long Drawing in Mojave Desert (California, USA) and thus commented on the work: "The line in the invisible drawing is like the mirage line of a heat wave in the desert floor, I mean it's something that's there and it's not there... But partially I think it was just instinct, just saying that aesthetically we can't do enough here in the city under this set of rituals and that the whole rules of the game have to be changed and that, if I go out and do this mile long piece, it's going to be a more powerful experience that just experiencing these few perfect sculptures in the gallery" [8].

The geometry does not even have to be seen - instead, it can be imagined, as in Antony Gormley's Horizon Field (2010-2012, Austrian Alps) where a hundred figures are scattered over an area of about $150 \mathrm{~km}^{2}$. Distances between individual figures range between several hundred meters and a few kilometers, so the composition cannot be seen as a whole. However, all figures are placed at the same altitude of $2039 \mathrm{~m}$ above sea level, forming an unseen horizontal plane crossing the mountainous terrain. This ambitious project, which required a lot of regulatory paperwork, accentuated the complexity of relations between man and nature. Gormley is sure that "no landscape is innocent, no landscape is uncontrolled; every landscape has a hidden social dimension" [42]. In another project, Event Horizon (2007-2010, London, UK, New York, USA, and other locations), Gormley aimed at making people stop for a moment and raise their eyes to the sky, to the horizon (which is unusually high in modern skyscraper cities). Figures were installed on rooftops, on the very edge, being visible from the ground level and seemingly watching the crowd from bird's eye perspective. The artist obviously reached his goal in regard to public reaction, as in all the cities where the project was on view the police registered record numbers of emergency calls informing about potential suicide jumpers.

In projects like this one, a sort of spatial tension occurs: whereas classical forms of art such as architecture or monumental sculpture are rooted in the ideas of tectonic vertical growth from below upwards, the artistic practices that deal with the landscape are mostly "horizontal," inseparably linked to the surface of the earth. However, Land Art is able to mark the spot just like a classical monument does it, though sometimes the object remains virtually unseen unless you fly over it or climb a nearby viewpoint. Thus, James Turrell's Irish Sky Garden (1992, Cork County, Ireland) is concealed inside a crater-like mound, and once the visitor gets inside and lies down on the stone bench in the center, their gaze is directed not on the object itself but rather on what is outside or above it - on the expanse of sky limited by the perfect elliptical brim of the mound. Turrell reaches a truly grand scale in his ongoing Roden Crater project (since 1974, Painted Desert, Arizona, USA) where an almost lunar landscape provides a perfectly flat, uninterrupted horizon line, a 360-degree panoramic view which pulls the viewer away from the everyday world. Turrell explains: "My desire is to set up a situation to which I take you and let you see. It becomes your experience... It's not taking from nature as much as placing you in contact with it" [37].

Such works that create "props" for the observation of nature and the skies are deeply linked to prehistoric and ancient rituals, as Lucy Lippard has shown in her Overlay [24]. In Observatorium (1977, Flevoland, Netherlands), Robert Morris aligns the "viewfinders," or openings in the double circular mound, with the positions of the sun in equinox and solstice days, offering the visitor a chance to meditate on natural phenomena such as the change of seasons [9, pp. 114-115]. 
Nancy Holt, also fascinated with astronomy, underlines the particular way of interaction between her works and the places she chooses for them: "In my Land Art dealing with astronomical phenomena, I am putting 'centers of the universe' wherever I go, making my work uniquely site-specific" [41, p. 60]. Holt aligns her concrete Sun Tunnels (1973-1976, Great Basin Desert, Utah, USA) (Ill. 61) along the axes of summer and winter solstices, creating "focus frames" for looking at the magnificent desert surroundings: "The panoramic view of the landscape is too overwhelming to take in without visual reference points. The view blurs out rather than sharpens. Through the tunnels, parts of the landscape are framed and come into focus" [17]. The walls of the tunnels are pierced with round holes of varying diameters - their patterns match the configurations of stars in the constellations of Capricorn, Draco, Perseus, and Columba. Rays of sun during the day stream through the holes and create ever-changing ornaments inside the tunnels ${ }^{3}$ - in Nancy Holt's words, "day is turned into night, and an inversion of the sky takes place: stars are cast down to Earth, spots of warmth in cool tunnels" [17]. This installation offers a framework for observing hourly, daily and seasonal changes in the universe. Holt perceives this process in poetic rather than mechanistic terms: "I feel that the need to look at the sky - at the moon and the stars - is very basic, and it is inside all of us. So when I say my work is an exteriorization of my own inner reality, I mean I am giving back to people through art what they already have in them." [30, p. 128] The artist expresses "a strong desire to make people conscious of the cyclical time of the universe" [41, p. 227]. Similarly, Charles Jencks in his Parco Portello (since 2002, Milan, Italy) proposes "rhythm of time" as key theme, finding visual metaphors for past and present, for linear and cyclic sequences of different scales and intensities, ranging from cosmic movements and global historical timelines to individual human heartbeats [11, pp. 109-113].

In some cases, the concept of the artwork so heavily relies upon astronomical and other scientific data that the site becomes a true observation station - the most ambitious and astonishing project of this kind is Charles Ross's Star Axis, ongoing since 1971 (Chupinas Mesa, New Mexico, USA). The artist, who studied mathematics and physics before turning to art, chose a very special spot for his masterwork: "I realized that the powerful spirit of this land gave me a feeling of standing on the boundary between Earth and Sky. Here both elements have equal weight and you can see the curvature of the Earth as you look out to the ocean of light that plays across the plains" [27, p. 52]. This unusual "curved" horizon can be experienced as one enters the complex and gradually ascends the central stairway, or Star Tunnel, which is aligned with the Earth's rotation axis. Looking up in between the rounded buttresses one can see the perfect circle of the skies, and time-lapse photos taken from several levels capture star trajectories of varying diameters - they show the orbit of the Pole Star and how the Earth's distance to it changed across millennia. Charles Ross explains, "The point of this art is to bring star geometry down into physical form and human scale" [19]. As John Beardsley puts it, this project renders time "less anthropocentric, less automatic, as we see ourselves relative to the cycles of a far greater duration and permanence than our own" [4, p. 73].

\footnotetext{
3 This effect can be compared to Étienne-Louis Boullée's famous project of Sir Isaac Newton's cenotaph (1784), where openings in the colossal sphere were intended to recreate the picture of night sky with star constellations.
} 
Thus, the notion of the horizon can be understood not only in the spatial but also in the temporal aspect, as many works bear a potential of growth, change, or development. Maya Lin remarked on this: "A lot of my works deal with a passage, which is about time. I don't see anything that I do as a static object in space. It has to exist as a journey in time" [38, p. 100]. However, the "positive" growth is not so frequent, always related to ecologically-oriented projects - such as those by Alan Sonfist, who draws public attention to the life and death of plants on our planet. For example, his Endangered Species of New England (2012, deCordova Sculpture Park and Museum, Massachusetts, USA) include steel silhouettes of leaves of sugar maple, blue oak, American chestnut and white elm (all currently on the verge of extinction), and capsules with seeds from the very same trees buried under each sculpture, as a symbolic "message in a bottle" for generations to come [11, p. 203]. Likewise, Agnes Denes's Tree Mountain - A Living Time Capsule - 11000 Trees, 11000 People, 400 Years (1992-1996, Ylöjärvi, Finland) is also facing the future. To create this massive piece, 11000 people from all over the world planted 11000 pine trees in a geometrical pattern on a conical mound. The participants were named custodians of the artwork, this title to be handed down in their families for 26 generations, or the next 400 years. The resulting landscape will be free of any construction or development during all this time, providing home for wildlife and preventing land erosion [9, p. 156].

More often, Land Art projects convey the idea of gradual destruction, annihilation, leveling out and becoming one and the same with the surrounding nature. Robert Smithson termed this process "entropy" and found the powerful visual metaphor for it in his Spiral Jetty (1969-1970, Great Salt Lake, Utah, USA) (Ill. 62). The spiral form of the work was suggested by a sense of motion and an eerie feeling of catastrophe present in the landscape. Smithson recalled: "As I looked at the site, it reverberated out to the horizons only to suggest an immobile cyclone while flickering light made the entire landscape appear to quake. A dormant earthquake spread into the fluttering stillness, into a spinning sensation without movement. This site was a rotary that enclosed itself in an immense roundness" [13, p. 146]. Nancy Holt, Smithson's wife, chimed in, calling Spiral Jetty "a vortex that draws in everything in the landscape around it" [9, p. 90]. The future of the artwork was to become an incarnation of this dramatic development: in the year of construction, waters of the lake were unusually low, but by 1976 Spiral Jetty was completely submerged. It resurfaced again in 2002, in a totally new look - salt crystals turned black basalt stones into shining white ones - a scenario that the artist could not foresee. So, Spiral Jetty outlived its creator and became the perfect expression of Smithson's concept of entropy, or "evolution in reverse" - the power of nature to obliterate itself and then to be reborn, the back-and-forth movement of all things on Earth. Smithson did not see entropy as a negative thing - though "irreversible," for him it was "a condition that's moving towards a gradual equilibrium" [13, p. 301], and the artist was "interested in collaborating with entropy" [13, p. 256].

Another example is Marinus Boezem's Green Cathedral (since 1987, Flevoland, Netherlands) (Ill. 63), where 187 poplars are planted according to a pattern that reproduces the architectural plan of Notre-Dame de Rheims in full scale. This type of tree, Populus nigra italica, is tall and slender, reminiscent of gothic proportions, but its life span is limited by approximately 30 years, which means that by now the trees have already started dying, and the "cathedral" is gradually decaying. The artist created the second part of the project as an acting reminder: in the neigh- 
boring plot, densely planted with long-living elms, oaks, and birch-trees, a grassy void is left, also mimicking the shape and size of Rheims cathedral. While the first "cathedral" is gradually vanishing, the second one will live on as its own "funeral monument" [9, pp. 118-119].

Similarly, Antony Gormley's Exposure (2010, Lelystad, Netherlands), installed on the seawall, is waiting patiently for its fate - either to be flooded when the sea level rises, or to be covered with soil when there is the need to raise the dam to prevent flooding. Danae Stratou literally visualizes Desert Breath (1997, Sahara Desert, Egypt) as the perfect pattern of fragile sand cones is gradually destroyed by winds. The idea of a disaster or some destructive power seems to fascinate many artists - it took Walter de Maria about five years to search for a landscape with a combination of "flatness, high lightning activity and isolation" [9, p. 107]. When the artist finally found the spot, he arranged 400 stainless-steel poles in a rectangular grid to create The Lightning Field (1977, New Mexico, USA), designed to conduct spectacular lightning during summer thunderstorms common in the area. As De Maria commented, "I like natural disasters and I think that they may be the highest form of art possible to experience... I don't think art can stand up to nature" [7].

Disasters lead to devastation - accordingly, in his famous and gigantic Double Negative (1969-1970, Mormon Mesa, Nevada, USA), Michael Heizer treats horizon as an absent structure, a figure of omission. The work consists of two huge rectangular trenches dug into the cliff, an eroded part of the mountain between them serving as a visual connection. The horizon here is perfectly natural and yet carefully manipulated by extracting material rather than accumulating it. This idea of the void is important for many Land Artists, as it complements and opposes the mound, the earth, the mass. Robert Smithson believed, "it is the dimension of absence that remains to be found" [13, p. 133].

This absence can be understood in a more emotional key, as a loss, and in this case, the very surface of the Earth can become a memorial, a sort of a "horizon of memory." Eloquent examples are Peter Eisenman's Memorial to the Murdered Jews of Europe (2003-2005, Berlin, Germany) and especially Alberto Burri's The Great Crack of Gibellina (1984-1989 and 2015, Sicily, Italy), a giant concrete installation created on the spot of the old town of Gibellina in Sicily, completely destroyed in 1968 earthquake. Burri created a sarcophagus in his trademark "crack" technique, literally cementing the ruins of the destroyed town, and preserving the map of its streets and squares for posterity.

The horizon is always associated with nostalgia, with a longing for the unreachable, because it inevitably moves away from us as we try to approach it. In Ian Hamilton Finlay's Little Fields, Long Horizons (1998, Little Sparta, Dunsyre, Scotland), three pairs of low drystone walls are installed at the edge of the artist's garden and invite the visitor to walk between them pondering on the following inscriptions:

LITTLE FIELDS - LONG HORIZONS

LITTLE FIELDS LONG - FOR HORIZONS

HORIZONS LONG - FOR LITTLE FIELDS

This elegant wordplay, together with the orientation of the stone blocks, draws the spectator's gaze to the horizon and introduces an oscillation between what is inside the garden and outside of it, what is near and far, here and there, what can be easily reached and what is inaccessible. 
Marina Abramović explicitly chose the Spanish province of Cádiz for her Human Nests project (2001, Montenmedio Arte Contemporáneo Foundation, Cádiz, Spain) - this area is literally the edge of the world, a crossroads between Europe and Africa, and a place where migrating birds rest every year. The rope ladders hanging from nests embedded in the solid rock are striking metaphors of the flight "on the other side" of horizon, which is so natural for the feathered tribe yet almost impossible for human beings [9, p. 220].

Crossing the horizon is a risky endeavor, and Christoph Gonnet visualizes this risk and makes the spectator feel it in the fragility and weakness of the wooden construction in his Passage of the Horizon (2013, Sancy Mountains, France). Krijn Giezen's Look Out Attention (1986-2005, Kröller-Müller Museum, Otterlo, Netherlands) literally allows for taking a look on the other side of the visible by means of climbing the high staircase that reaches the brim of the dune - quite ironically, for most part of the time this work is closed due to hazards and unavailable for visits, and the horizon remains beyond our reach. However, if one is lucky enough to go up, the line between the earth and the sky will be as distant as before. Robert Smithson noted this irresolute and utopian longing for the unattainable: "One is always crossing the horizon, yet it always remains distant. In this line where sky meets earth, objects cease to exist" [13, p. 119].

Smithson's perception of the landscape was quite poetical and philosophical, and the theme of the horizon regularly occurs in his writings. Following his steps, numerous artists boldly aspire to visualize and interpret this symbolic idea in their work. They do it in various ways, yet another quote from Smithson perfectly sums up their intentions and outcomes: "Once you get there, there's no destination... so the site is evading you all the while it's directing you to it... There is no subject to go toward... There's no way to find what's out there... The location is held in suspense" [13, p. 218].

Thus, in this paper, we have observed how, from the late 1960s onwards, the new perception of nature and its relations with culture led to the emergence of radically different spaces intended for exhibiting artworks. The pioneering views of Robert Smithson helped define a new creative practice - Land Art, with the notion of site and the concept of site-specificity being central to it. Born in the landscape, Land Art projects transform their surroundings - in some cases, by adding to them, in other cases - by subtracting from them. The immediate bodily experience of the viewer plays a crucial part in such works, as it becomes a way to reconnect with the inherent geometry of nature. In many projects, the line of the horizon, accentuated or concealed, real or imaginary, serves as the perfect embodiment of this geometry in all its inevitability and elusiveness. This spatial construct always comes with a bit of nostalgia and unresolved longing for the unreachable, especially in the cases where the temporal aspect of the horizon is evoked - again, in line with Smithson's idea of entropy. In this respect, scale becomes the major factor of expression, especially in projects that deal with larger-than-life phenomena such as cosmic movements and cycles - their frequent reappearance in contemporary art draws a bridge toward the most ancient rituals and testifies to the continuity of human nature.

\section{References}

1. Abrioux Y. Ian Hamilton Finlay: A Visual Primer. London, Reaktion Books Publ., 1992. 318 p.

2. Arnason H. H.; Mansfield E. C. History of Modern Art: Painting, Sculpture, Architecture, Photography. New York, Pearson Publ., 2012. 832 p. 
3. Barlow N.; Knox T.; Holmes C. Follies of Europe: Architectural Extravaganzas. Woodbridge, Garden Art Press Publ., 2008. 256 p.

4. Beardsley J. Probing the Earth: Contemporary Land Projects. Washington, Smithsonian Institution Press Publ., 1977. 112 p.

5. Cézanne P. Letter to Émile Bernard, 15 April 1904. Letters of the Great Artists - from Blake to Pollock. London, Thames \& Hudson Publ., 1963. 288 p.

6. Davies P.; Knipe T. (eds.). A Sense of Place: Sculpture in Landscape. Sunderland, Sunderland Arts Centre and Coelfrith Gallery Publ, 1984. 176 p.

7. De Maria W. On the Importance of Natural Disasters. An Anthology of Chance Operations. New York, La Monte Young \& Jackson Mac Low Publ., 1963. 120 p.

8. De Maria W. Oral History Interview. Smithsonian Archives of American Art, 1972, October 4. Available at: https://www.aaa.si.edu/collections/interviews/oral-history-interview-walter-de-maria12362\#transcript (accessed 14 January 2019).

9. Dempsey A. Destination Art: Land Art, Site-Specific Art, Sculpture Parks. London, Thames \& Hudson Publ., 2011. 288 p.

10. Dixon Hunt J. Nature Over Again: The Garden Art of Ian Hamilton Finlay. London, Reaktion Books Publ., 2008. 198 p.

11. Dixon Hunt J. The Making of Place: Modern and Contemporary Gardens. London, Reaktion Books Publ., 2015. 302 p.

12. Eyres P.; Russell F. (eds.). Sculpture and the Garden. Burlington, Ashgate Publ., 2006. 196 p.

13. Flam J. D. (ed.). Robert Smithson: The Collected Writings. Berkeley; Los Angeles; London, University of California Press Publ., 1996. 390 p.

14. Glancey J. Totally Cosmic: The Life Mounds of Charles Jencks. The Guardian, 2011, June 22. Available at: https://www.theguardian.com/artanddesign/2011/jun/22/charles-jencks-life-mounds-architecture (accessed 14 January 2019).

15. Gormley A. Antony Gormley on Sculpture. London, Thames \& Hudson Publ., 2015. 240 p.

16. Heizer M. Interview with Julia Brown. Michael Heizer: Sculpture in Reverse. Los Angeles, Museum of Contemporary Art Publ., 1984. 112 p.

17. Holt N. Sun Tunnels. Artforum, 1977, vol. 15, no. 8, pp. 32-37. Available at: https://www.artforum.com/ print/197704/sun-tunnels-35992 (accessed 14 January 2019).

18. Judd D. Specific Objects. Arts Yearbook, 1965, vol. 8, pp. 180-190.

19. Karlin S. A Sculptor Works Up an Exposé of the Stars' Secrets. The New York Times, 2002, November 3. Available at: https://www.nytimes.com/2002/11/03/arts/art-architecture-a-sculptor-works-up-anexpose-of-the-stars-secrets.html (accessed 14 January 2019).

20. Kaye N. Site-Specific Art: Performance, Place and Documentation. New York, Routledge Publ., 2008. 238 p.

21. Kimmelman M. Michael Heizer: A Sculptor's Colossus of the Desert. The New York Times, 1999, December 12. Available at: https://archive.nytimes.com/www.nytimes.com/library/arts/121299heizerart.html (accessed 30 January 2019).

22. Krauss R. Passages in Modern Sculpture. New York, Viking Press Publ., 1977. 320 p.

23. Krauss R. Sculpture in the Expanded Field. October, 1979, vol. 8, pp. 30-44.

24. Lippard L. Overlay: Contemporary Art and the Art of Prehistory. New York, Pantheon Books Publ., 1983. 272 p.

25. Long R. Richard Long: Walking in Circles. London, Southbank Centre Publ., 1991. 264 p.

26. O'Doherty B. Inside the White Cube: The Ideology of the Gallery Space. Berkeley, Los Angeles, University of California Press Publ., 1999. 116 p.

27. Oakes B. (ed.). Sculpting with the Environment: A Natural Dialogue. London, International Thomson Publ., 1995. $252 \mathrm{p}$.

28. Potteiger M.; Purinton J. Landscape Narratives: Design Practices for Telling Stories. New York, Wiley Publ., 1998. 342 p.

29. Rigaud A. Disorienting Geographies: Land Art and the American Myth of Discovery. Miranda, 2012, no. 6. Available at: https://journals.openedition.org/miranda/2955 (accessed 14 January 2019).

30. Saad-Cook J.; Ross Ch.; Holt N.; Turrell J. Touching the Sky: Artworks Using Natural Phenomena, Earth, Sky and Connections to Astronomy. Leonardo, 1988, vol. 21, no. 2, pp. 123-134. Available at: https://www.jstor.org/stable/1578546 (accessed 14 January 2019).

31. Sanford M. The Salt of the Earth Sculpture: Debating Intervention As Nature Does Its Work. The New York Times, 2004, January 13. Available at: https://www.nytimes.com/2004/01/13/arts/the-salt-of-theearth-sculpture-debating-intervention-as-nature-does-its-work.html (accessed 14 January 2019). 
32. Sheeler J. Little Sparta: A Guide to the Garden of Ian Hamilton Finlay. Edinburgh, Birlinn Publ., 2015. 196 p.

33. Sleeman J. 1977. A Walk Across the Park, Into the Forest, and Back to the Garden: The Sculpture Park in Britain. Sculpture and the Garden. Burlington, Ashgate Publ., 2006, pp. 157-169.

34. Smithson R. A Sedimentation of the Mind: Earth Projects. Artforum, 1968, vol. 7, no. 1, pp. 44-50.

35. Thiberghien G. Land Art. Paris, Carré Publ., 1993. 312 p.

36. Tillim S. Earthworks and the New Picturesque. Artforum, 1968, vol. 7, no. 4, pp. 42-45.

37. Turrell J. Mapping Spaces: A Topological Survey of the Work. New York, Peter Blum Publ., 1987. 94 p.

38. Waterman T. The Fundamentals of Landscape Architecture. Lausanne, AVA Publ., 2009. 200 p.

39. Weilacher U. Between Landscape Architecture and Land Art. Basel; Berlin; Boston, Birkhäuser Publ., 1999. 240 p.

40. Weilacher U. In Gardens: Profiles of Contemporary European Landscape Architecture. Basel; Berlin; Boston, Birkhäuser Publ., 2005. 184 p.

41. Williams A. J. (ed.). Nancy Holt: Sightlines. Berkeley; Los Angeles; London, University of California Press Publ., 2011. 296 p.

42. Wroe N. Leader of the Pack. The Guardian, 2005, June 25. Available at: http://www.theguardian.com/ artanddesign/2005/jun/25/art (accessed 14 January 2019).

Title. Horizon as a Symbolic Category in Contemporary Site-Specific Art

Author. Kochetkova, Ekaterina Sergeevna - Ph. D., head lecturer. Lomonosov Moscow State University, Leninskie Gory, 1, 119991 Moscow, Russian Federation. katerina.kochetkov@gmail.com

Abstract. This paper intends to investigate various practices in contemporary art that intervene in landscape surroundings. These forms of art have a privilege of not just depicting or imagining natural phenomena, but using them directly as essential components of the work. Thus, in this essay the category of horizon is treated in a very "palpable" way, though metaphorical and poetical at the same time. The physical and symbolic presence and interpretation of horizon in the art of the last five decades constitute the subject of this survey. The artistic strategies reviewed here include artificial creation or accentuation of the horizon line, massive interventions in the surface of the Earth, mechanisms of visual perception and focusing attention, exploration of spatial as well as temporal aspects of the notion, and many more. The concept of the horizon is present in the works of Ian Hamilton Finlay, Antony Gormley, Michael Heizer, Nancy Holt, Maya Lin, Walter de Maria, Robert Morris, Charles Ross, Richard Serra, Robert Smithson, James Turrell, and other artists. By addressing this theme, they utilize a wide range of media to remind us that the horizon is a utopian expression of the eternal longing for the unreachable.

Keywords: Site-specific art, Land Art, Earthworks, landscape art, Minimalism, Conceptual Art, Postmodernism, art of the later $20^{\text {th }}$ century, contemporary art

Название статьи. Горизонт как символическая категория в современном сайт-специфическом искусстве

Сведения об авторе. Кочеткова Екатерина Сергеевна - кандидат искусствоведения, старший преподаватель. Московский государственный университет имени М. В. Ломоносова, Ленинские горы, д. 1, Москва, Российская Федерация, 119991. katerina.kochetkov@gmail.com

Аннотация. В настоящей статье исследуются различные практики современного искусства, непосредственно работающие с ландшафтом. Уникальность подобных художественных форм состоит в том, что они не просто изображают или воспроизводят явления природы, но используют их напрямую, как неотъемлемые составляющие произведения. Таким образом, в этом тексте понятие горизонта рассматривается в очень конкретном и «осязаемом» ключе, но в то же время метафорически и поэтически. Предметом исследования являются физическое и символическое присутствие и интерпретация идеи горизонта в искусстве последних пяти десятилетий. Изучаемые здесь художественные стратегии включают искусственное создание или подчёркивание линии между небом и землёй, крупномасштабные вторжения в ландшафт, механизмы визуального восприятия и фокусировки внимания, пространственное и временно́е понимание горизонта, и многое другое. Над понятием горизонта размышляют такие художники, как Энтони Гормли, Майя Лин, Уолтер де Мария, Роберт Моррис, Чарльз Росс, Ричард Серра, Роберт Смитсон, Джеймс Таррелл, Ян Гамильтон Финлей, Майкл Хейзер, Нэнси Холт и другие. Обращаясь к этой теме, они разными средствами напоминают нам о том, что горизонт есть утопическое выражение вечного стремления к недостижимому.

Ключевые слова: сайт-специфическое искусство, ленд-арт, земляные работы, ландшафтное искусство, минимализм, концептуальное искусство, постмодернизм, искусство второй половины ХХ века, современное искусство 


\section{61. Nancy}

Holt. Sun Tunnels. 1973-1976. Great Basin Desert, Utah, USA (C) Photo: Retis https://www. flickr.com/photos/85264217@ N04/21255793405

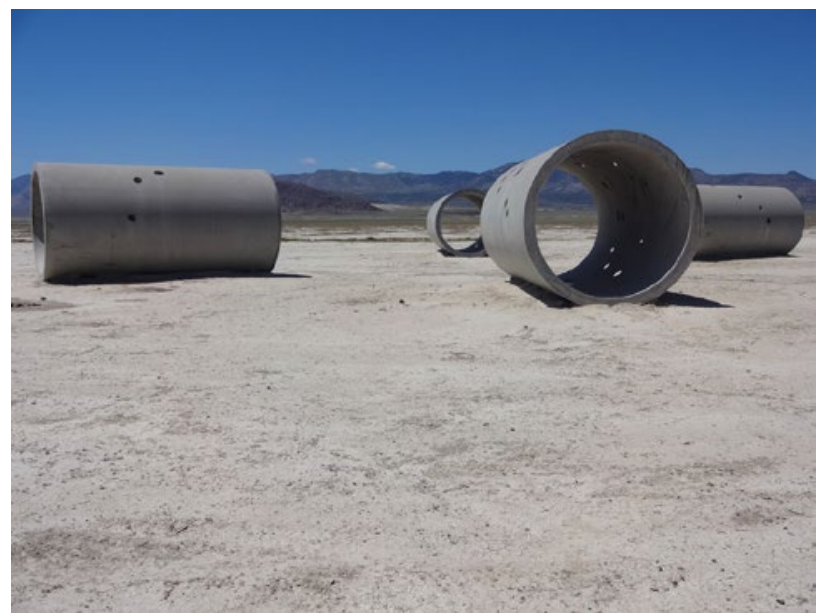

\section{62. Robert}

Smithson.

Spiral Jetty.

1969-1970. Great Salt Lake, Utah, USA (C) Photo: Retis https://www. flickr.com/photos/85264217@ N04/20801602334

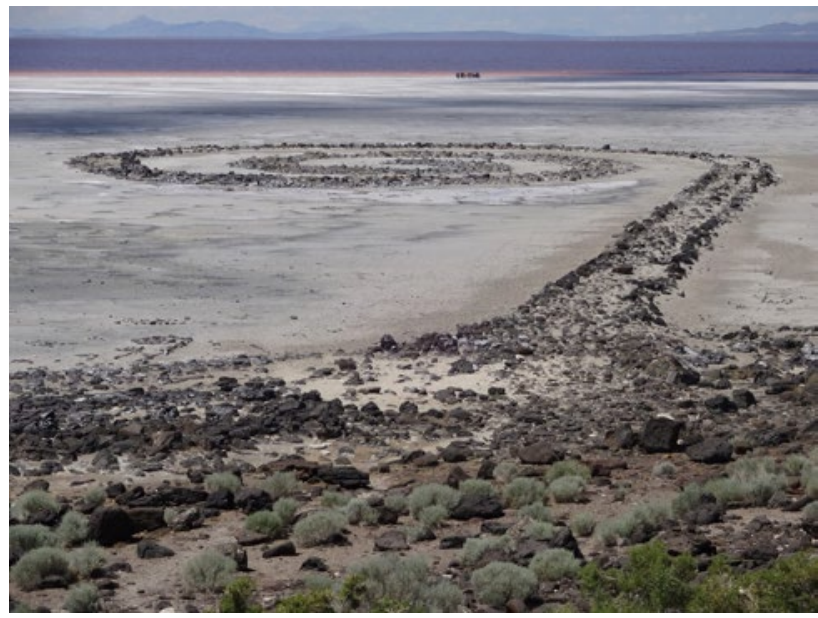

III. 63. Marinus Boezem. Green Cathedral. Since 1987. Flevoland, Netherlands (C) Photo: RogAir https://commons. wikimedia. org/wiki/ File:GOPR0061. MP4_000124020. jpg

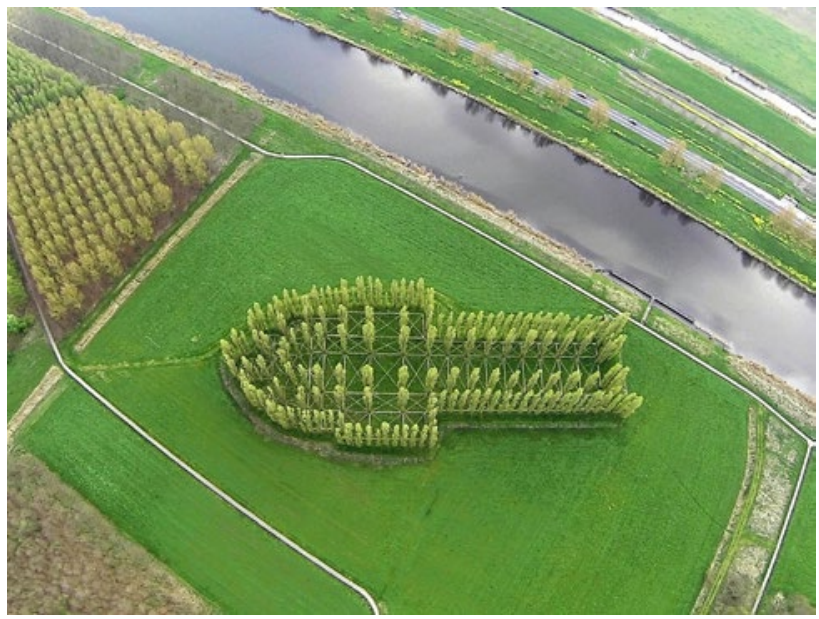

